\title{
Turystyka przemysłowa w Tarnowskich Górach
} Industrial tourism in Tarnowskie Góry

\author{
Magdalena Kowol ${ }^{1}$, Paweł Różycki ${ }^{2}$ \\ ${ }^{1} J a s t r z e ̨ b s k a$ Spółka Węglowa S.A. Kopalnia Węgla Kamiennego „Krupiński” \\ ul. Piaskowa 35, 43-267 Suszec; e-mail: magdalenakowol@interia.pl \\ ${ }_{2}^{2}$ Instytut Turystyki i Rekreacji, Akademia Wychowania Fizycznego w Krakowie, \\ Al.Jana PawłaII 78, Kraków; e-mail: itrozycki@o2.pl
}
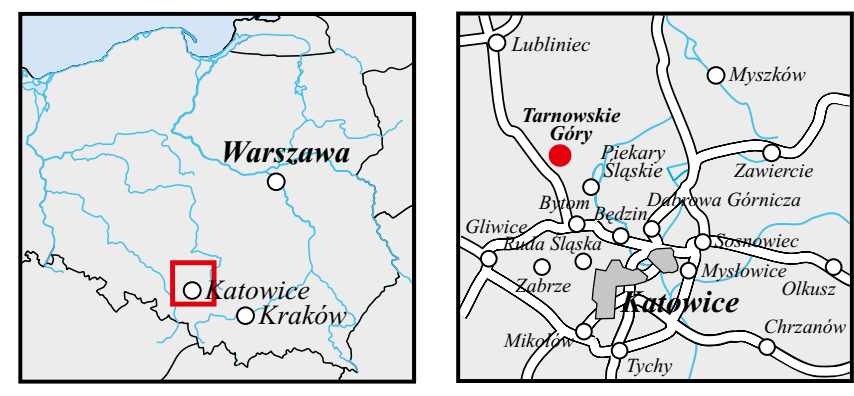

Treść: $W$ artykule dokonano analizy rozwoju turystyki przemystowej i geoturystki w oparciu o istniejqce walory znajdujqce się na terenie Tarnowskich Gór. Jest to jedno z najciekawszych miast w Polsce, posiadajacych walory, które stanowia dziedzictwo narodowe zwiqzane z rozwojem górnictwa i przemystu. Zwrócono również uwage na możliwości rozwoju tych form turystyki, które mogq stać się szansq rozwoju miasta przez turystykę. Powiazania przemystu, geologii i turystyki sq w Tarnowskich Górach aż nadto widoczne. Autorzy artykulu starali się to wyeksponować.

Słowa kluczowe: turystyka przemystowa, turystyka postindustrialna, geoturystyka

Abstract: The state of development of attractions, basing on the product of industrial tourism and geotourism in Tarnowskie Góry, has been analysed in the article. Tarnowskie Góry is one of the most fascinating cities in Poland possessing great value that constitute national heritage as far as development of mining and industry is concerned. Considerable attention has been given to the possibility of development of these forms of tourism which can become a chance for the city's development via tourism. The interrelations between industry, geology and tourism are clearly visible in Tarnowskie Góry. Thus the authors of this paper have aimed at highlighting that very fact.

Keywords: industrial tourism, post-industrial tourism, geotourism

W ostatnich latach turystyka przeżywa okres dynamicznego rozwoju, związane jest to między innymi ze zjawiskiem globalizacji. Wraz ze wzrostem ruchu turystycznego niemal w każdej części świata następuje rozwój produktu turystycznego. Turyści poszukują nowych doznań i nowych propozycji. Jedną z nich jest pojawiająca się oferta turystyki przemysłowej i geoturystyki. Poszukiwania turystów w zakresie różnorodnego spędzania czasu wolnego, spowodowały powstanie i rozwój wielu odmian tak zwanej turystyki specjalnych zainteresowań. Proces ten został zapoczątkowany w krajach wysoko rozwiniętych. Tam przeżywa swój największy rozkwit. Przejawia się w tym, że turyści odchodzą od tradycyjnych form spędzania czasu wolnego, a w zamian szukają takich, które zaspokoją ich zainteresowania w bardzo wąskiej dziedzinie. Jedną z takich form jest właśnie turystyka postindustrialna nazywana również przemysłową lub industrialną. Polega ona na zwiedzaniu czynnych obiektów przemysłowych lub w przypadku turystyki postindustrialnej także obiektów zamkniętych, a które jeszcze niedawno były zakładami pracy (Różycki, 2006). W Polsce jest to zjawisko relatywnie nowe, chociaż w niektórych miejscach ma już swoje tradycje (Wieliczka, Bochnia, Krzemionki Opatowskie oraz Tarnowskie Góry). Mimo to, nie jest jeszcze produktem powszechnie oferowanym na krajowym rynku turystycznym. Tymczasem dobre wykorzystanie zabytków przemysłu i techniki może uatrakcyjnić już istniejącą ofertę turystyczną, bądź stworzyć nową, gdyż często jest tak, że obiekty przemysłowe sa jedynymi cennymi zabytkami w danej miejscowości. W ostatnich latach można obserwować w kraju modę na adaptację obiektów poprzemysłowych, szczególnie związanych z górnictwem. Do ciekawszych przykładów należą: kopalnie węgla kamiennego w Nowej Rudzie i w Zabrzu, kopalnia złota w Złotym Stoku, kopalnia uranu w Kletnie. Warto dodać, że zabytki techniki i przemysłu coraz częściej stają się obiektem zainteresowań nie tylko wąskiej grupy specjalistów, ale również turystów, którzy są zainteresowani poznaniem dziedzictwa kulturowego konkretnego regionu. Oferta turystyki przemysłowej znakomicie uzupełnia tradycyjny produkt turystyczny oparty na walorach antropogenicznych, w tym głównie na obiektach architektonicznych. $Z$ turystyką przemysłową wiąże się często geoturystyka. Polega ona na poznawaniu obiektów i procesów geologicznych oraz doznawaniu w kontakcie z nimi wrażeń estetycznych (Słomka, Kicińska-Świderska, 2004).

Na ogół jest tak, iż w regionach, w których obiekty przemysłowe powstały w oparciu o istniejące na danym terenie surowce mineralne, obecnie rozwija się turystyka przemysłowa. Przykładem mogą być takie ośrodki jak wcześniej wymienione: Zabrze, Nowa Ruda, Złoty Stok lub Wałbrzych. Zatem w dobie rozwoju turystyki są one doskonałym przykładem łączenia produktu turystycznego turystyki przemysłowej i geoturystyki.

Na terenie Polski znakomitym przykładem tego połączenia są właśnie Tarnowskie Góry. Położone są na Wyżynie Śląskiej, 25 kilometrów na północny zachód od Katowic. Początek miastu dała osada Tarnowice Stare, wzmiankowana już w XIII wieku. Od XVI wieku, kiedy Tarnowskie Góry uzyskały prawa miejskie, miasto stało się na kilka wieków centrum śląskiego górnictwa srebra oraz cynku i ołowiu. Obecnie najważniejszymi obiektami przyciągającymi turystów są: zabytkowa Kopalnia Rud Srebronośnych i Sztolnia „Czarne- 
go Pstrąga". Tarnowskie Góry to jeden z najstarszych ośrodków górniczych w Europie. Stąd też historia miasta i okolic ściśle wiąże się z rozwojem górnictwa, a później także hutnictwa.

\section{Charakterystyka środowiska przyrodniczo-geograficznego}

\section{Położenie, uksztaltowanie terenu i krajobraz}

Według podziału fizyczno-geograficznego (Kondracki, 2000), rejon Tarnowskich Gór położony jest na granicy dwóch mezoregionów.

W południowej, większej części miasta jest to Garb Tarnogórski, wchodzący w skład Wyżyny Śląskiej. Stanowi on element Progu Środkowo Triasowego (Fig.1.), który ze względu na swe wykształcenie należy do najbardziej typowych krawędzi morfologicznych w Polsce (Gilewska, 1963). [Od północy graniczy z Doliną Małej Panwi, od południa z Płaskowyżem Bytomsko-Katowickim, od wschodu z Kotliną Józefki, zaś od zachodu z Garbem Laryszowskim (Szaflarski, 1956; Karaś-Brzozowska, 1960; Gilewska,1972)]. Płaskowyż Tarnowicki jest wyniesiony w stosunku do otaczających go elementów morfologicznych i odcina się od nich łagodnymi stokami o wysokości od $10 \mathrm{~m}$ do około $70 \mathrm{~m}$. Jego powierzchnia jest falista i wynosi około $110 \mathrm{~km}^{2}$, generalnie wykazuje nachylenie w kierunku południowo-zachodnim. W centralnej części płaskowyżu, pomiędzy wyraźnie zaznaczającymi się obniżeniami, wyodrębnia się szereg garbów, a wśród nich garb tworzony przez Srebrną Górę, Suchą Górę i Cipiorę.

Północne krańce miasta zostały zaliczone do Równiny
Opolskiej, należącej do Niziny Śląskiej. Są to tereny położone w Dolinie Małej Panwi i jej dopływu Stoły, stanowiące obniżenie o charakterze pradoliny. Jej powierzchnia tworzy płaskie i monotonne działy porośnięte lasem, nachylenia nie przekraczają tu 5\%. Miejscami powierzchnia działów została przekształcona przez procesy eoliczne, dzięki którym wykształciły się pola wydmowe utrwalone obecnie przez roślinność. Takie niewielkie wydmy o długości 200-1100 m, urozmaicają wschodnią część wspomnianej Doliny Małej Panwi (Hadaś, 2000).

Współczesna rzeźba powierzchni Tarnowskich Gór to efekt oddziaływania w minionych epokach wielu czynników naturalnych, takich jak: ruchy tektoniczne, procesy denudacyjne i akumulacyjne oraz współcześnie wpływających czynników antropogenicznych. Główne jej rysy powstały $\mathrm{w}$ miocenie, kiedy to w wyniku tortońskich ruchów tektonicznych został utworzony Próg Środkowotriasowy. Bardzo dobrze widać to w części centralnej i wschodniej opisywanego obszaru, gdyż pokrywa utworów czwartorzędowych jest tam bardzo cienka lub wcale jej nie ma (Lamparska-Wieland, 2003; Hadaś, 2000). Jednak szczególne znaczenie w kształtowaniu współcześnie obserwowanej rzeźby terenu i krajobrazu odegrały przeobrażenia spowodowane działalnością lodowców i gospodarczą działalnością człowieka (Żeglicki, 2002).

\section{Zarys budowy geologicznej regionu Tarnowskich Gór}

Wraz z odkryciem w XII wieku złóż kruszców srebra, rud cynku i ołowiu oraz żelaza, rozpoczęło się rozpoznawanie

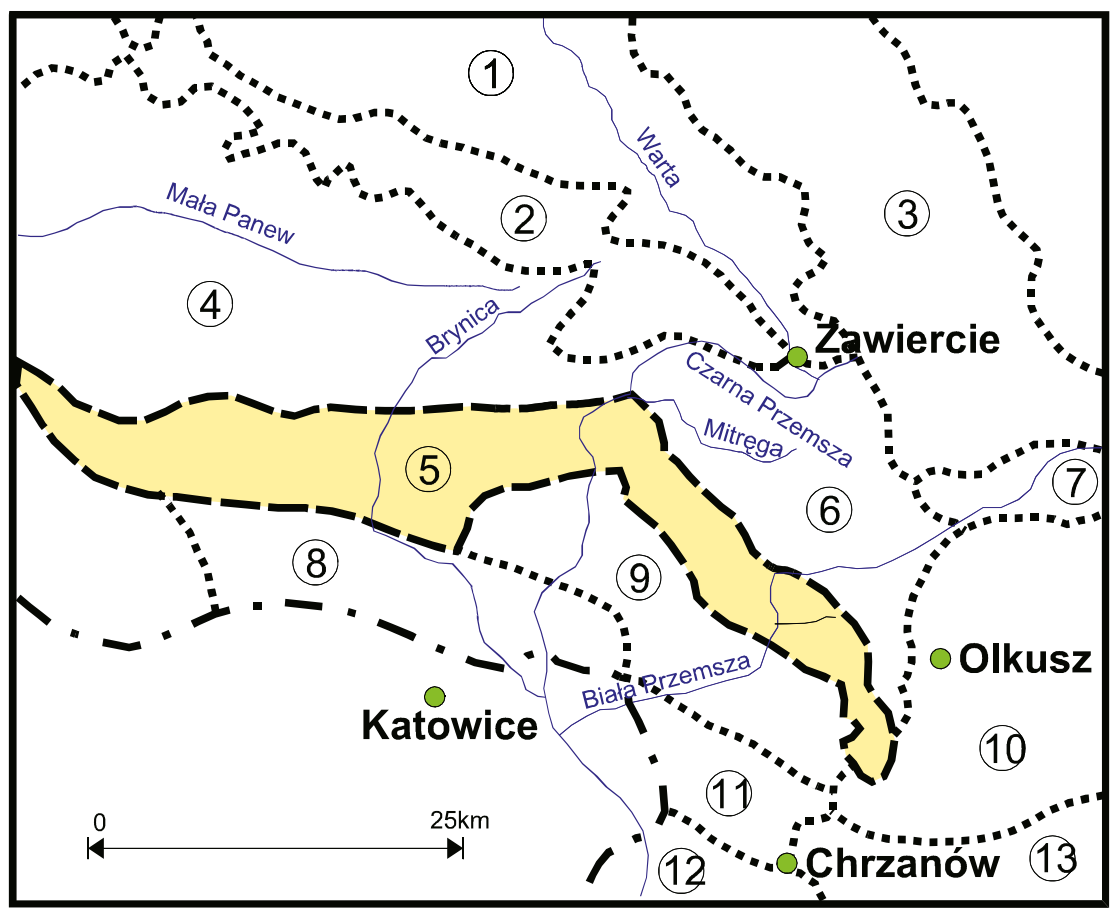

Fig. 1. Szkic geomorfologiczny obszaru Śląsko - Dąbrowskiego (Żeglicki, 2002). Objaśnienia: 1 - Obniżenie Górnej Warty (Dolina Górnej Warty), 2 - Próg Woźnicki (Próg Górnotriasowy), 3 - Wyżyna Częstochowska (Płaskowzgórze Częstochowskie), 4 - Dolina Małej Panwi, 5 - Garb Tarnogórski (Próg Środkowotriasowy), 6 - Kotlina Mitręgi, 7 - Brama Wolbromska, 8 - Górnośląski Okręg Przemysłowy (Płaskowyż Bytomsko - Katowicki), 9 - Kotlina Przemszy, 10 - Wyżyna Olkuska (Płaskowyż Ojcowski), 11 - Niecka Wilkszyńska, 12 - Rów Chrzanowski, 13 - Rów Krzeszowicki 
utworów budujących Płaskowyż Tarnowicki. Badania te kontynuowane były przez kolejne pokolenia górników i mierniczych.

Tarnowskie Góry leżą w obrębie permsko-mezozoicznej pokrywy platformowej tworzącej monoklinę śląsko-krakowska. Pokrywa ta zalega na utworach starszych, paleozoicznokarbońskich i dewońskich. W okolicy miasta przebiega granica paleozoicznej struktury - zapadliska górnośląskiego, którego warstwy ciągną się od południa i zanikają w okolicy Tarnowskich Gór (Kerber, 1977; Szaflarski, 1956).

Utwory triasu zalegają dyskordantnie na nierównym stropie utworów karbońskich, który wykazuje zapadanie w kierunku północno zachodnim, pod kątem $2-3^{\circ}$ i dodatkowo charakteryzuje się obecnością nieciągłych deniwelacji wzdłuż licznych uskoków, o zrzutach dochodzących do $70 \mathrm{~m}$. Warstwy triasowe zalegające równolegle do powierzchni stropu karbońskiego, odznaczające się zmienną zwięzłością, wytworzyły od strony wschodniej progi kuestowe (LamparskaWieland, 2003).

Utwory permsko-mezozoiczne zostały sfałdowane podczas ruchów górotwórczych, w wyniku czego powstały jednostki strukturalne zwane nieckami. Jedną z nich jest położona na południe od Tarnowskich Gór wyraźnie zaznaczająca się niecka bytomska o osi na kierunku W-E, ciągnąca się od miejscowości Miechowice do Czeladzi. Inna, słabiej zaznaczająca się to asymetryczna niecka tarnogórska, zwana też tarnowicką, o kierunku osi głównej NW-SE (Piekary Śląskie-Laryszów).

Od niecki bytomskiej oddziela ją drobne w wymiarach i łagodne w wykształceniu siodło, biegnące ze wschodu na zachód. Od strony północnej ogranicza ją niewielka antyklina o przebiegu z SE na NW od Nakła Śląskiego do Repecka. Dalej w kierunku na północ rozwija się ona w rozległą mo- noklinę. Obie niecki powstały w wyniku waryscyjskich ruchów górotwórczych, których główne nasilenie przypada na górny karbon (około 260 milionów lat temu). Zostały odnowione podczas laramijskich ruchów górotwórczych, na przełomie kredy i trzeciorzędu (około 60 milionów lat temu) (Lamparska-Wieland, 2003; Żeglicki, 1996). Schematyczny zarys wyżej wymienionych niecek obrazuje Fig. 2.

Zbiorcze dane dotyczące litologii i stratygrafii osadów z okolic Tarnowskich Gór, Miotka i Kalet zostały przedstawione w tabeli litologiczno-stratygraficznej - Fig. 3 .

\section{Atrakcyjność turystyczna i walory Tarnowskich Gór}

Atrakcyjność turystyczną określa się jako stopień przyciągania przez dany region określonej liczby i rodzaju turystów. Jest to jednak subiektywna cecha, gdyż dany walor może być odbierany przez jednego turystę jako atrakcyjny, dla drugiego może być obojętny, zaś dla trzeciego może mieć znacznie pejoratywne (Kruczek, 2002).

Walory turystyczne według kryterium genetycznego dzieli się na naturalne (przyrodnicze) i kulturowe (antropogeniczne). Według kryterium funkcjonalnego dzieli się je na trzy grupy: walory krajoznawcze, specjalistyczne i wypoczynkowe.

Atrakcyjność turystyczną Tarnowskich Gór podnoszą niewątpliwie walory przyrodnicze miasta. Są to między innymi parki, skwery i ogrody miejskie, a wśród form chronionych spotyka się liczne pomniki przyrody, rezerwat przyrody i zespół przyrodniczo-krajobrazowy. Wśród parków na uwagę zasługują: Park Miejski i Park Repecki. Znaczący walor stanowi również Ogród Plebański w Starych Reptach mieszczący się przy parafii św. Mikołaja. W ogrodzie tym,

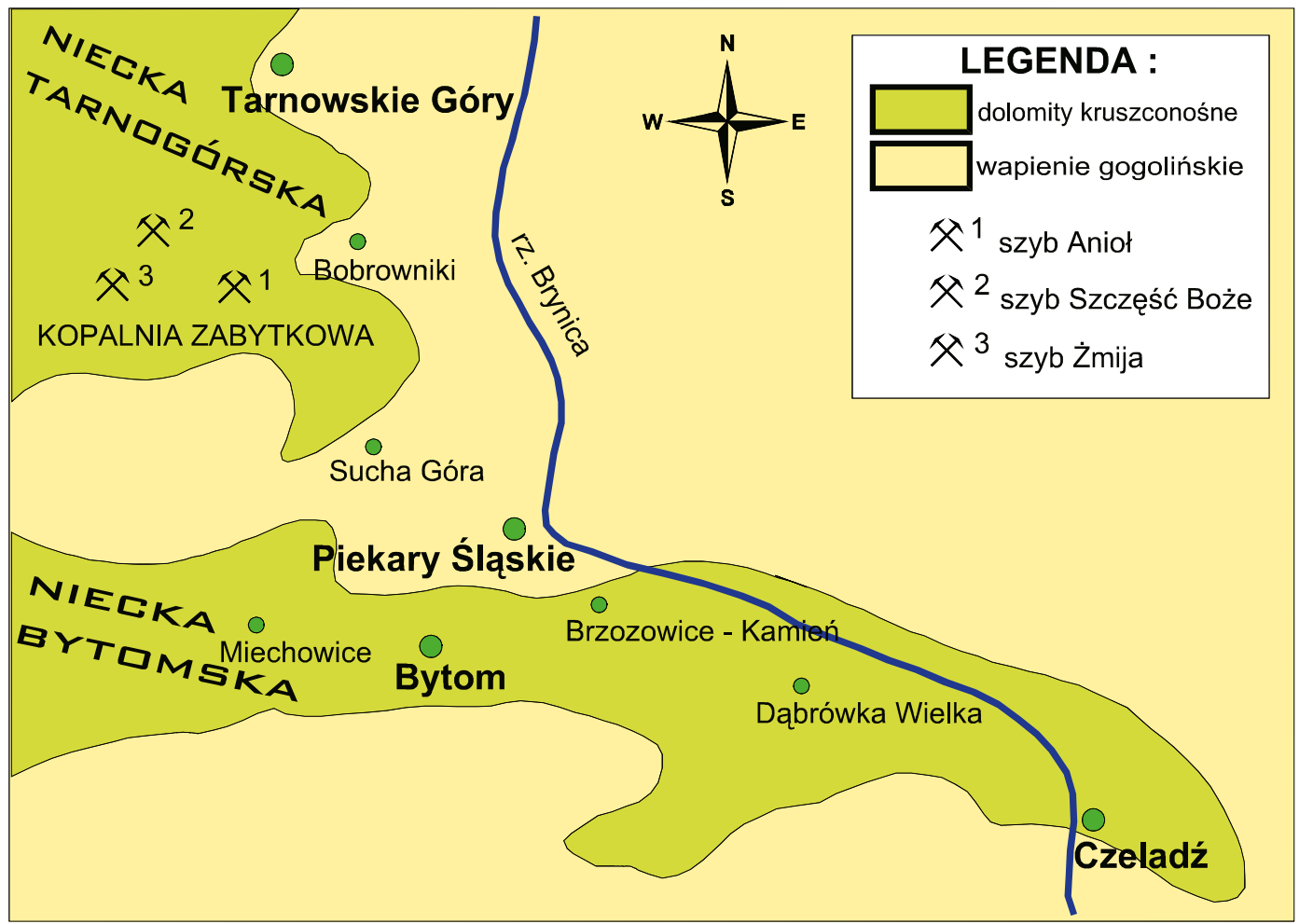

Fig. 2. Schematyczna mapa niecki bytomskiej i tarnogórskiej (Żeglicki, 2002) 


\begin{tabular}{|c|c|c|c|c|c|c|c|c|}
\hline & \multicolumn{5}{|c|}{ Stratygrafia } & $\begin{array}{l}\text { Miąższość } \\
\text { w m }\end{array}$ & \multicolumn{2}{|l|}{ Litologia } \\
\hline & \multicolumn{5}{|c|}{ Czwartorzęd } & do 50 & \multicolumn{2}{|l|}{ gliny, piaski, żwiry, mułki } \\
\hline \multirow{9}{*}{ 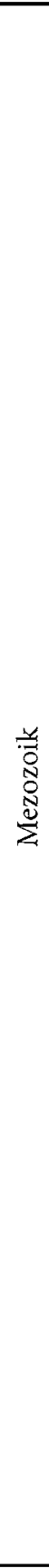 } & $\stackrel{\circledast}{巳}$ & \multicolumn{4}{|c|}{ dolna } & & \multicolumn{2}{|c|}{$\begin{array}{l}\text { glinki ogniotrwałe, żwiry, zlepieńce, piaski } \\
\text { kwarcowe, piaskowce żelaziste, wkładki } \\
\text { iłów i mułowców (w kotłach krasowych na } \\
\text { wapieniu muszlowym) }\end{array}$} \\
\hline & \multirow{8}{*}{$\overbrace{\mathscr{E}}^{\infty}$} & \multicolumn{4}{|c|}{ Retyk } & do 80 & \multicolumn{2}{|c|}{$\begin{array}{l}\text { iły, iłowce oraz mułowce pstre i szare, } \\
\text { wkładki piaskowców, margli, dolomitów, } \\
\text { brekcji i wapieni }\end{array}$} \\
\hline & & \multirow{5}{*}{ 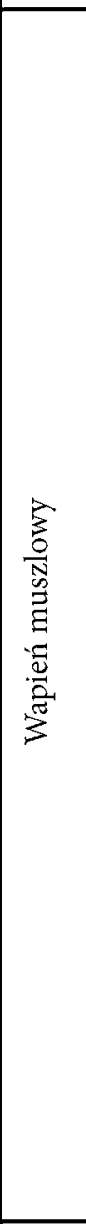 } & \multicolumn{3}{|c|}{$\begin{array}{l}\text { warstwy boruszo- } \\
\text { wickie } \\
\text { wilkowickie }\end{array}$} & $\begin{array}{c}\text { około } \\
8-12 \\
2-10 \\
15-18\end{array}$ & \multicolumn{2}{|c|}{$\begin{array}{l}\text { margle ilaste i iły, przewarstwienia dolomi- } \\
\text { tów, wkładki piaskowców i wapieni } \\
\text { wapienie i dolomity, dolomity margliste, } \\
\text { wkładki zlepieńcowe } \\
\text { dolomity margliste z laminami iłów, } \\
\text { wkładki wapieni }\end{array}$} \\
\hline & & & 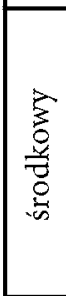 & $\begin{array}{r}\text { dolon } \\
\text { diplope }\end{array}$ & & $\begin{array}{l}\text { około } \\
25-40\end{array}$ & $\begin{array}{l}\text { dolomity diploporowe, } \\
\text { przeławicowania wapieni, } \\
\text { na N i NW od Kalet do- } \\
\text { minuja wapienie i wapie- } \\
\text { nie dolomityczne, w rejo- } \\
\text { nie Kalet - rudy Zn-Pb }\end{array}$ & $\begin{array}{l}\text { Dolomity } \\
\text { kruszconoś- } \\
\text { ne; szare, kry- } \\
\text { staliczne } \\
\text { i ziarniste, } \\
\text { kawerniste, } \\
\text { porowate; } \\
\text { miejscami }\end{array}$ \\
\hline & & & & $\begin{array}{l}\text { warst } \\
\text { karcho } \\
\text { terebrat } \\
\text { gorazdz }\end{array}$ & $\begin{array}{l}\text { icki } \\
\text { icki } \\
\text { lowe } \\
\text { ískie }\end{array}$ & $\begin{array}{l}\text { łącznie } \\
\text { około } \\
40-50\end{array}$ & $\begin{array}{l}\text { wapienie krystaliczne lub } \\
\text { pelityczne z rogowcami, } \\
\text { miejscami z fauną, kawer- } \\
\text { niste, w części północnej } \\
\text { nierozpoziomowane }\end{array}$ & $\begin{array}{l}\text { dolomity } \\
\text { wapniste; } \\
\text { wkładki iłów } \\
\text { i margli. } \\
\text { Okruszcowa- } \\
\text { nie } \mathrm{Zn-Pb;}\end{array}$ \\
\hline & & & $\frac{\widehat{\Xi}}{\frac{\partial}{\sigma}}$ & $\begin{array}{c}\text { warstwy } \\
\text { gogolińskie }\end{array}$ & górne & $\begin{array}{l}\text { około } \\
30-45\end{array}$ & $\begin{array}{l}\text { Wapienie, wapienie mar- } \\
\text { gliste, faliste, wkładki iłów } \\
\text { i margli, wapienie zlepień- } \\
\text { cowe, w części południo- } \\
\text { wej wykształcone typowo } \\
\text { dla obszaru śląsko-kra- } \\
\text { kowskiego; w części pół- } \\
\text { nocnej - nietypowe, trudne } \\
\text { do rozpoziomowania }\end{array}$ & $\begin{array}{l}\text { miąższość } \\
\text { ok. } 25-60 \mathrm{~m}\end{array}$ \\
\hline & & & & & dolne & $\begin{array}{l}\text { około } \\
10-20\end{array}$ & $\begin{array}{l}\text { Wapienie, wapienie marglis } \\
\text { lomitów; wapienie faliste, } \mathrm{g} \\
\text { iłem; u dołu wapienie } \mathrm{z} \text { fau } \\
\text { krynoidów, wykształcone n } \\
\end{array}$ & $\begin{array}{l}\text { e, wkładki do- } \\
\text { uzłowate z } \\
\text { ą małzów i } \\
\text { ogół typowo }\end{array}$ \\
\hline & & $\stackrel{\mathscr{U}}{3}$ & & górny ret & & $\begin{array}{l}\text { około } \\
40-80\end{array}$ & $\begin{array}{l}\text { Dolomity, dolomity marglist } \\
\text { ki wapieni jamistych; niżej } \\
\text { wkładki piaskowców, dolor } \\
\text { w części północnej wkładk }\end{array}$ & $\begin{array}{l}\text { lokalne wkład- } \\
\text { y i margle szare, } \\
\text { itów i wapieni, } \\
\text { gipsów }\end{array}$ \\
\hline & & 焉 & & $\begin{array}{r}\text { dolny i środl } \\
\text { (niższy) }\end{array}$ & & do 25 & $\begin{array}{l}\text { Pstre iły, iłowce, piaski, pia } \\
\text { we, wkładki zlepieńców (m } \\
\text { dolomitów dewońskich) }\end{array}$ & $\begin{array}{l}\text { kowce kwarco- } \\
\text { n. z otoczakami }\end{array}$ \\
\hline$\frac{y}{3}$ & Perm & & & wony spągov & & do 400 & $\begin{array}{l}\text { Pstre lub czerwone piask } \\
\text { (otoczaki porfirów, wapieni } \\
\text { piaskowców, spoiwo ilasto } \\
\text { tufowe) }\end{array}$ & $\begin{array}{l}\text { wce i zlepieńce } \\
\text { łupków kwarcu, } \\
\text { węglanowe lub }\end{array}$ \\
\hline$\frac{\sqrt{3}}{8}$ & Karbon & Kar & bon $q$ & rny - Namur & (warst) & y brzeżne) & $\begin{array}{l}\text { Łupki ilaste, iłowce, mułc } \\
\text { szare, wkładki węgli }\end{array}$ & Nce, piaskowce \\
\hline & & & & Karbon & olny & & $\begin{array}{l}\text { Lupki ilaste-piaszczyste sza } \\
\text { skowców i zlepieńców }\end{array}$ & e; wkładki pia- \\
\hline & Dewon & & & Dewon śro & kowy & & Dolomity i wapienie & \\
\hline
\end{tabular}

Fig. 3. Tabela litologiczno - stratygraficzna utworów geologicznych w okolicy Kalet, Miotka i Tarnowskich Gór (Żeglicki, 2002) 
założonym prawdopodobnie już w średniowieczu, rośnie kasztan jadalny. Jego wiek ocenia się na 450 lat i jest to przypuszczalnie najstarszy tego typu okaz w Europie Środkowej. W 1960 roku został on uznany za pomnik przyrody.

Tarnowskie Góry posiadają szereg zabytkowych obiektów i budowli. Ich powstanie należy wiązać z okresem rozwoju górnictwa cynku i ołowiu. Pierwsze budowle murowane pochodzą z początku XVI wieku. Materiałem budowlanym były miejscowe wapienie i piaskowce kładzione na zaprawie wapiennej. W wyniku pożarów niszczących miasto, jak i przebudowy, która miała miejsce w latach 30-tych XX wieku, wiele unikalnych obiektów zniknęło na zawsze, bądź ich pierwotny wygląd uległ zmianie.

Rynek - serce miasta - ma kształt trapezu. Jego wymiary to: 108 metrów długości, 75 metrów szerokości w części zachodniej i 52 metry - we wschodniej. W XIX wieku został wybrukowany tak zwanymi „kocimi łbami”. Pozostałości tamtej nawierzchni zostały zachowane przy odrestaurowanej studni miejskiej. W trakcie wykopalisk w 2004 roku natrafiono na znacznie starsze pokrycie rynku z otoczaków, pochodzące z XVI wieku. Studnia symbolizuje historyczne punkty czerpania wody i jest niezaprzeczalnie wizytówką miasta.

Na uwagę zasługuje gmach ratusza, uważany za jeden z najpiękniejszych na Śląsku. Wzniesiono go w latach 1896$98 \mathrm{w}$ stylu renesansu północnego z elementami gotyckimi. Jest to trzykondygnacyjny, narożny budynek, którego dach wieńczy drewniana wieżyczka. Narożnik ratusza zdobi pięć herbów wykutych w piaskowcu. Od strony rynku są to kolejno: herb Śląska, herb Cesarstwa Niemieckiego, herb nadany Tarnowskim Górom w 1562 roku, herb Królestwa Prus i herb magnackiej rodziny Henckel von Donnersmarck. Na fasadzie, W niszy po prawej stronie budynku umieszczona została w 1959 roku postać gwarka tarnogórskiego. Poniżej znajduje się herb margrabiego Jerzego von Ansbacha, który przyczynił się do rozwoju miasta i górnictwa tarnogórskiego (Wyżgoł i in., 2004).

Do godnych zwiedzenia obiektów zlokalizowanych wokół rynku należy zaliczyć kamienicę z XVI wieku zwaną „Domem Sedlaczka”. Pierwotnie znajdowała się tam siedziba starostów ziemi bytomsko-tarnogórskiej, gościli w niej również Jan III Sobieski, August II Mocny, Goethe i Niemcewicz. W 1805 roku nabył ją kupiec Jan Sedlaczek. Na parterze i w piwniczkach urządził winiarnię, która istnieje do dzisiaj (Wyciszczak, 2000). Na pierwszym piętrze w Domu Sedlaczka mieści się od 1958 roku Muzeum Tarnogórskie. Powstało ono z inicjatywy zasłużonego dla ziemi tarnowickiej Stowarzyszenia Miłośników Ziemi Tarnogórskiej. Zgromadzone są w nim zbiory związane z historią i kulturą tarnogórskich ziem (Krzykowska i in., 1998).

Do interesujących elementów kultury tarnogórskiej zaliczają się kapliczki, krzyże i figury świętych. Przeważnie były to kluczowe punkty krajobrazu jak rozstaje dróg czy miejsca pracy. Najliczniejsze w Tarnowskich Górach są obiekty związane z Janem Nepomucenem, patronem dobrej spowiedzi, tonących, dobrej sławy i mienia. W górniczym mieście, jakim są Tarnowskie Góry, nie mogło zabraknąć miejsc kultu świętej Barbary - patronki górników i hutników. Grotę z figurą świętej ustawiono przy byłej Kopalni Dolomitów, natomiast podziemna kapliczka znajduje się w Zabytkowej Kopalni Rud Srebra.

\section{Turystyka przemyslowa, zabytki techniki i geoturystyka}

\section{Sztolnia „Czarnego Pstrąga”}

Sztolnia „Czarnego Pstrąga” to udostępniony turystycznie fragment Głębokiej Sztolni Fryderyk, wydrążonej w skale dolomitowej w latach 1821-1834. Jest to najdłuższa i zarazem najgłębsza sztolnia w tarnogórskim systemie odwadniającym wyrobiska górnicze. Drążenie sztolni wymagało od ówczesnych górników rozwiązania wielu problemów, co przy XIXwiecznych możliwościach technicznych nie było zadaniem łatwym. Wysoka dokładność mierniczych pozwoliła na drążenie sztolni 14 przodkami równocześnie. W trudnych warunkach geologicznych (kurzawki, miejscami słaby strop, bardzo silne zawodnienie). Dużym wyzwaniem było utrzymanie odpowiedniego kierunku i wzniosu. Ponadto, do celów transportowo-wentylacyjnych wykonano 26 szybów. Dwa z nich, szyb „Ewa” i ,Sylwester” wykorzystuje się obecnie do wejścia i wyjścia z trasy turystycznej.

Bardzo dobrze zachowane, oryginalne partie chodnika sztolniowego, jak również rosnące zainteresowanie turystów podziemiami tarnogórskimi, nasunęły jednemu z członków sekcji penetrujących tę sztolnię pomysł, aby w Sztolni „Fryderyk" uruchomić przeprawę łodziami. Trasa miała powstać między szybami 13 i 17 pod Parkiem Repeckim. Początkowo myśl ta nie spotkała się z akceptacją Zarządu Stowarzyszenia Miłośników Ziemi Tarnogórskiej (SMZT) ze względu na dużą odległość od śródmieścia i brak połączenia autobusowego Parku Repeckiego z centrum miasta. Jednak w sytuacji, kiedy termin oddania do użytku Kopalni Zabytkowej oddalał się w czasie, Zarząd SMZT zdecydował się udostępnić sztolnię dla ruchu turystycznego. Dobry stan techniczny sztolni, jak i obu szybów nie wymagał dużych nakładów finansowych.

W górnictwie europejskim panuje obyczaj zmiany nazwy obiektów górniczych w związku ze zmianą ich użytkowania. Stąd też nadano nowe nazwy sztolni i szybom wentylacyjnym. Nazwa obiektu Sztolnia „Czarnego Pstrąga” pochodzi od zaobserwowanych tam pstrągów, które choć są koloru tęczowego, w świetle lampy karbidowej wydawały się czarne. Udostępnianie turystyczne sztolni odbywało się etapami. Pierwsi turyści zwiedzili sztolnię 15 września 1957 roku podczas „Dni Gwarków”. Początkowo turyści schodzili szybem „Ewa”, po przepłynięciu 300 metrów, zawracali i wychodzili tym samym szybem na powierzchnię. Taki ruch odbywał się do momentu, kiedy zbudowano schody w szybie „Sylwester”. Oddanie całego odcinka Sztolni „Czarnego Pstrąga" nastąpiło 6 września 1958 roku podczas kolejnych „Dni Gwarków”.

Ruch w sztolni odbywa się w sposób wahadłowy. Raz szybem zjazdowym jest szyb „Ewa”, a drugim razem „Sylwester". Oba te szyby ukryte są w zieleni rozległego Parku Repeckiego. Trasa turystyczna ciągnie się na 600-metrowym odcinku sztolni, której wysokość waha się od 2,2 do 4 metrów, a szerokość od 1,3 do 2,5 metra. Zestaw turystyczny liczy 10 łodzi, do których jednorazowo może wsiąść od 40 do 60 osób. Temperatura powietrza oscyluje w granicach $10{ }^{\circ} \mathrm{C}$. Głębokość wody w sztolni nie przekracza 1 metra. Przewodnicy przeprawiają turystów od jednego szybu do drugiego, odpy- 
chając od ociosów skalnych stalowe łodzie. Na trasie zwiedzania, która trwa około 1 godziny, obserwuje się wydrążoną w dolomitach sztolnię.

Wyrazy uznania należy skierować w stronę przewodników sztolniowych. Ich ciężka, a zarazem niecodzienna praca, bo wykonywana pod ziemią, jest godna podziwu. Przy świetle lamp górniczych, w tajemniczej atmosferze półmroku i ciszy, niestrudzenie snują ciekawe opowieści i legendy górnicze, których często są autorami. Dzięki ich staraniom zwiedzanie Sztolni „Czarnego Pstrąga” jest niezapomnianym przeżyciem dla każdego turysty. Sztolnia „Czarnego Pstrąga”, reprezentuje unikatowe walory jako zabytek techniki i specjalistyczny obiekt geoturystyczny.

\section{Kopalnia Zabytkowa Rud Srebronośnych}

Tarnogórskie podziemia, niezbadany i rozległy labirynt chodników, sztolni i wyrobisk górniczych, od zawsze fascynowały i zachęcały do poznania tego, co nieznane. Stąd też już w okresie międzywojennym zrodził się pomysł udostępnienia społeczeństwu unikalnych podziemi górniczych. Moment zwrotny nastąpił w 1934 roku, kiedy burmistrzem Tarnowskich Gór został prawnik Fryderyk Antes. Powołał on i stanął na czele komisji badającej podziemia. Cztery lata później władze miasta otrzymały długo oczekiwane nadanie górnicze pod budowę Kopalni Pokazowej - jak wówczas określano Kopalnię Zabytkową Rud Srebronośnych. Jeszcze w tym samym roku do miasta przyjechało 5000 turystów, którzy zwiedzili fragment podziemi (wykorzystano wtedy szyb „Staszic”, który posiadał urządzenie przystosowane do transportu ludzi). Jednak kres planom odbudowy kopalni położyła II wojna światowa.

Trzy lata po zakończeniu wojny sztygar Alfons Kopia kontynuował plany uruchomienia Kopalni Zabytkowej. Od 1953 roku, kiedy powstało Stowarzyszenie Miłośników Historii i Zabytków Ziemi Tarnogórskiej, rozpoczęło się bardzo intensywne badanie dawnych wyrobisk górniczych. Uroczyste otwarcie kopalni zabytkowej nastąpiło 5 września 1976 roku. Termin ten pokrył się z rocznicą 450 -lecia założenia górniczego miasta. W tym dniu pierwsza grupa zwiedziła Zabytkową Kopalnię Kruszców, oprowadzana przez członków Stowarzyszenia Miłośników Ziemi Tarnogórskiej.

Trasa turystyczna prowadzi przez niewielki fragment, bo tylko 1740 metrów, zrekonstruowanych wyrobisk górniczych pochodzących z XVI-XIX wieku. Kształtem przypomina trójkąt, którego wierzchołkami są trzy szyby: „Anioł”, „Szczęść Boże” i „Żmija”. Atrakcyjne odcinki trasy eksponowane są za pomocą ciekawych efektów świetlnych.

Do podziemi zjeżdża się wyciągiem szybowym w szybie Anioł na głębokość 40,5 metra. Następnie chodnikiem „Staszica” dochodzi się do pierwszej komory zwanej „Srebrna”. $\mathrm{Na}$ powierzchni $500 \mathrm{~m}^{2}$ zachowanej w naturalnej postaci, zostały odtworzone stanowiska pracy gwarków. Warto zwrócić uwagę na bardzo dobrze zachowany strop, który wzmocniono obudową kotwową. Ekspozycję tworzą także pozostawione narzędzia i sterta urobionej rudy. W głębi komory znajduje się niewielkie jeziorko oraz pozostałości niewydobytej galeny. Z komory „Srebrnej”, idąc za chodnikiem międzykomorowym, dochodzi się do kolejnej komory „Zawałowej”. Zachowano jej naturalną postać z czasów osiem- nastowiecznej eksploatacji. W jej centralnej części stoją oryginalne wózki z XVIII wieku wypełnione urobkiem.

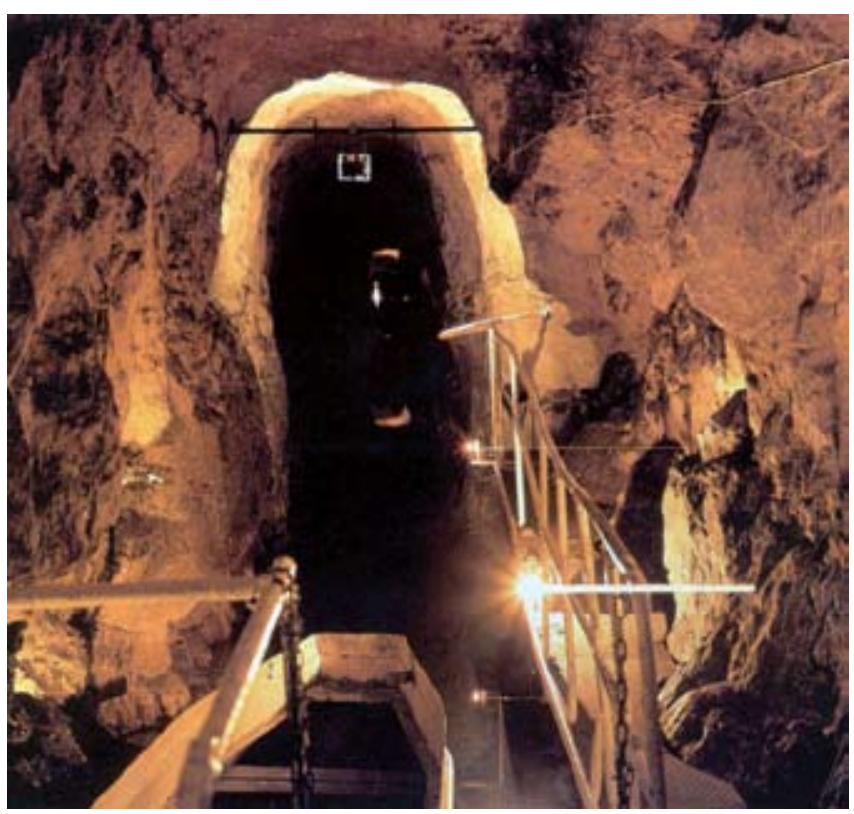

Fig. 4. Kopalnia Zabytkowa Rud Srebronośnych - fragment trasy turystycznej, fot. M. Kowol

Kolejnym etapem zwiedzania jest przepłynięcie łodziami 270 metrowej trasy w kierunku szybu „Żmija”. Od przystani w szybie „Żmija”, trasa prowadzi prosto w kierunku szybu „Anioł”. Idąc chodnikami z XVII i XVIII wieku, można zobaczyć fragmenty obudowy wapiennej na zaprawie wapiennopiaskowej, która przetrwała do dnia dzisiejszego w nienaruszonym stanie. Przechodzi się także fragmentem chodnika wykonanego w trakcie odbudowy kopalni, zwanym „Obejście”. Ostatni odcinek trasy - chodnik transportowy „Garusa” - prowadzi do podszybia szybu „Anioł”, skąd za pomocą urządzenia transportowego wraca się na powierzchnię.

Po wyjściu z podziemi, warto zwiedzić na powierzchni Muzeum Górnictwa, w którym prezentowane są narzędzia i makiety urządzeń górniczych stosowanych w górnictwie tarnogórskim (Moszny, 2001; Piernikarczyk, 2002).

\section{Skansen Maszyn Parowych}

XIX wiek, zwany epoka pary i stali, pozostawił po sobie stare i nieprzydatne urządzenia, z których wiele przepadło bezpowrotnie. Te, które ocalały, zgromadzone są w kilkunastu skansenach na terenie kraju, z czego trzy znajdują się na Śląsku, a najstarszy z nich, z 1976 roku w Tarnowskich Górach. Otwarcie skansenu odbyło się równocześnie $\mathrm{z}$ udostępnieniem trasy turystycznej w zabytkowej kopalni. Pierwsi zwiedzający zobaczyli wówczas następujące eksponaty: maszynę wyciągową typu bębnowego z kopalni ,Śląsk z 1903 roku; maszynę wyciągową typu Koepe z 1883 roku z kopalni „Śląsk”; platformę ze zbiornikiem wyprodukowaną w 1884 roku, przekazaną przez Koleje Dojazdowe Bytom; parowóz wąskotorowy PX5 - 1614 z 1930 roku wyprodukowany przez Polską Wytwórnię Parowozów, a przekazany przez podlubelską parowozownię w Karczmiskach; parowóz wąskotorowy T49-116 powstały w 1950 roku w Chrzanowie, pozyskany od Dyrekcji Okręgowej Kolei Państwowych w Poznaniu; parowy walec drogowy z 1928 roku wyproduko- 
wany przez Towarzystwo Akcyjne Cegielski w Poznaniu, przekazany przez Powiatowy Zarząd Dróg Lokalnych w Oświęcimiu, dłutownicę typu PMZ 92, dzieło Maschinen Fabrik Reitbauer K.U.K Hoflieferant z Wiednia (1914), która poprzednio znajdowała się w Sanoku; kocioł parowy lokomobilowy z 1910 roku i pompe parową Worthigton przekazaną przez Przedsiębiorstwo Kopalnictwa Gazu Ziemnego z Sanoka.

Z upływem lat maszyn przybywało. Dziś można w Skansenie Maszyn Parowych zobaczyć 31 niepowtarzalnych obiektów. Jednym z eksponatów wzbudzających powszechne zainteresowanie jest zabytkowe koło wodne z XVII wieku. Służyło ono do napędzania młota w kuźnicach w Strzybnicy.

Warto zaznaczyć, iż tarnogórski skansen znajdujący się w sąsiedztwie Kopalni Zabytkowej Rud Srebronośnych jest doskonałym uzupełnieniem tego, co turysta może zobaczyć pod ziemią.

\section{Ruch turystyczny}

Od otwarcia Sztolni „Czarnego Pstrąga” w 1957 roku następował systematyczny wzrost liczby zwiedzających ten obiekt. W roku 1968 ruch turystyczny osiągną poziom 40000 wejść i w latach 1969-1980 kształtował się na podobnym poziomie.

W ciągu kolejnych dwudziestu lat - do 2000 roku, zauważa się znaczne wahania liczby turystów odwiedzających sztolnię. Powodowały je czasowe przerwy w ruchu turystycznym związane ze zmianą poziomu wody w sztolni. Wpływała na nie również aktualna sytuacja polityczno-gospodarcza kraju. Liczba zwiedzających utrzymywała się średnio w granicy 55 000, przy czym największy spadek nastąpił w 1985 roku - zanotowano wówczas 35840 osób, zaś w 1995 roku sztolnię przepłynęło prawie 66000 turystów, a w 2004 roku około 41000 turystów (dane uzyskano z muzeum).

Największy odsetek wśród zwiedzających stanowią turyści uprawnieni do opłat ulgowych. Ich liczba w ostatnich latach wzrosła i obecnie stanowi 93\% wszystkich zakupionych biletów. Są to głównie uczniowie szkół podstawowych, gimnazjalnych i średnich. Turyści zagraniczni stanowią około 4\% wszystkich zwiedzających. Przyjeżdżają głównie grupami, ale zdarzają się też turyści indywidualni. Są to głównie obywatele Niemiec i Stanów Zjednoczonych.

Zaledwie rok po otwarciu Kopalni Zabytkowej Rud Srebronośnych liczba odwiedzających wzrosła z kilkuset do ponad 30 000. Przez 14 lat zainteresowanie tarnogórskimi podziemiami stale rosło. Wyjątek stanowiły lata 1981-1983, kiedy wprowadzono stan wojenny w Polsce. W 1988 roku liczba zwiedzających przekroczyła 70 000, a w 1997 roku około 100 tys. Na początku XXI wieku liczba ta spadła do 67 tys. w 2004 roku.

\section{Promocja i reklama regionu}

Tarnowskie Góry są niewątpliwie miejscem o znacznym nagromadzeniu walorów przyrodniczych i antropogenicznych, które wyróżniają się wysoką atrakcyjnością. Poza tym dogodne położenie komunikacyjne i zauważalny w ostatnich latach rozwój bazy noclegowej i gastronomicznej stwarzają dogodne warunki do rozwoju ruchu turystycznego na tym obszarze. Jednak, aby przyciągnąć większą liczbę turystów, potrzebna jest odpowiednia promocja i reklama.
Ważnym wydarzeniem w dziejach tarnogórskich podziemi było wpisanie w kwietniu 2004 roku przez Prezydenta Rzeczypospolitej Polskiej, Zabytkowej Kopalni Rud Srebronośnych i Sztolni „Czarnego Pstrąga” na Listę Pomników Historii. Wpis ten nastąpił w odpowiednim momencie, gdyż w ostatnich latach zmniejszyła się liczba turystów odwiedzających kopalnię. Obecność na niej jest znakiem prestiżu i sposobem na zainteresowanie zabytkami techniki większej liczby turystów z kraju i ze świata. Promocja Tarnowskich Gór odbywa się również poprzez nawiązanie współpracy z Powiatem Tucholskim (województwo kujawsko-pomorskie), Departamentem Saony i Loary (Francja, Burgundia) i Powiatem Erlangen-Hochstadt (Niemcy, Bawaria). Za cel wyznaczono sobie wzajemne poznanie i wymianę doświadczeń.

\section{Podsumowanie}

Tarnowskie Góry obfitują w różnorodne i cenne walory krajoznawcze i specjalistyczne. Dają one podstawę do rozwoju różnych form turystyki, w tym turystyki przemysłowej. Wzrost znaczenia turystyki postindustrialnej i geoturystyki wiąże się z pozytywnymi skutkami dla rozwoju regionalnego. Poprzez podniesienie atrakcyjności turystycznej kreuje się pozytywny wizerunek miasta i rejonu, jako miejsca lokalizacji nowych inwestycji. Stworzenie kompleksowego pakietu atrakcji zwiększa szanse na zatrzymanie turystów w mieście na dłuższy okres czasu. Współpraca międzygminna na polu turystyki, powinna przyczynić się do uatrakcyjnienia tego pakietu. Tak powstały nowy produkt turystyczny będzie atrakcyjny zarówno dla turysty krajowego, jak i zagranicznego.

Promocja regionu, mimo że jest prowadzona na wielu płaszczyznach, w znacznej mierze ma znaczenie lokalne. Dlatego priorytetem w polityce miasta i powiatu powinno być dotarcie do szerszego grona odbiorców. Skutecznie przeprowadzona kampania reklamowa nowopowstałego produktu turystycznego spowoduje wzrost zainteresowania regionem i zachęci do odwiedzenia miasta.

Barierą w rozwoju nowych form turystyki jest zaobserwowana niska świadomość społeczeństwa o wartości zabytków techniki. Przekłada się ona na stosunkowo małe zainteresowanie dziedzictwem przemysłowym. Uzasadnia to potrzebe zapoczątkowania akcji informacyjnej w mediach publicznych na rzecz turystyki przemysłowej. Jest to o tyle ważne, gdyż w powszechnym przekonaniu panuje pogląd o niskich walorach historycznych, architektonicznych i kulturalnych obiektów dziedzictwa przemysłowego. Jednak turyści, którzy chociaż raz odkryli walory dziedzictwa przemysłowego, chętnie w przyszłości poszukują podobnych obiektów. Ważne jest również kształtowanie świadomości młodych pokoleń na wszystkich szczeblach edukacji. Znakomitym przykładem może być Projekt Edukacji Regionalnej „Indianer”, którego celem jest ukazanie dziedzictwa kulturowego Ziemi Tarnogórskiej i stworzenie baz danych o tarnogórskiej tematyce. Turystyka industrialna jest coraz bardziej popularną formą spędzania czasu w krajach Unii Europejskiej. Stąd też warto czerpać wzorce i opierać się na istniejących w tym zakresie doświadczeniach. Turystyka industrialna i geoturystyka stanowią znaczący element urozmaicający ofertę turystyczną regionów przemysłowych. 


\section{Summary \\ Industrial tourism in Tarnowskie Góry}

\author{
Magdalena Kowol, Paweł Różycki
}

Together with the growth of tourist movement, the development of tourist product is recognizable almost in the whole world. Tourists are in search of new experiences and new offers. One of them is the offer of industrial tourism and geotourism. The tourists' quest for varied ways of spending their free time has led to the creation and development of a great variety of so called special interest tourism. The mentioned process has started in highly developed countries, where it fully blooms. It is realized via tourists' considerable turn-away from traditional forms of spending their free time. Instead, they seek such forms that can satisfy their interests in very specialised fields.

Post-industrial tourism, a branch of industrial tourism, is one of the mentioned forms. Industrial tourism is visiting working factories and plants, whereas in case of post-industrial tourism, tourists visit closed working places (Różycki, 2006). In Poland this phenomenon is relatively new, though, it has its traditions in certain places (Wieliczka, Bochnia, Krzemionki Opatowskie and Tarnowskie Góry). Still it is not a widely available product on the local tourist market. Yet a well-thought use of the relics of industry and technology may make an existing tourist offer more attractive or it may even create a completely new tourist offer since in many places industrial buildings are the only places worth visiting.

In the last years, a certain fashion of adapting post-industrial buildings, especially the ones connected with mining, can be noticed. The offer made by industrial tourism is an excellent complement to the traditional tourist product based on cultural value, in particular the value of architectural objects. Industrial tourism is often connected with geotour- ism. Geotourism is based on studying geological objects and processes which provide one with esthetic impressions (Słomka, Kicińska-Świderska, 2004).

Tarnowskie Góry is situated in Silesian Upland on Permian-Mesozoic platform cover which makes Silesian-Cracovian monocline. The mentioned cover is placed in two older ones- Palaeozoic-Carboniferous and Devonian. Near the city there appears a border of a Palaeozoic structure- Upper Silesian Depresssion, the strata of which stretch from the South and disappear near Tarnowskie Góry (Kerber, 1977; Szaflarski, 1956).

Among the great number of tourist attractions in the city there are: Black Trout Adit, the Ancient Mine of Silver-bearing Ores and Heritage Museum of Steam-Engines.

Promotion of the region, even though conducted on various grounds, to a large measure has a local significance. Therefore, it should be of top priority for politicians of the city to reach a greater number of potential tourists. An effectively-conducted advertising campaign of a newly-created tourist product will cause growth in the interest into the region and it will encourage people to visit the city.

The observed low society's awareness of the value of the technological relics makes a barrier for the development of new forms of tourism. It results in relatively low interest in industrial heritage. All of it justifies the need for informative campaign in public media to promote industrial tourism. It is very important since people seem to believe that objects of industrial heritage possess low historical, architectural and cultural value. However, tourists who, at least once, discovered the value of the industrial heritage, in the future willingly search for similar objects. It is also vital to form awareness of young generations at all levels of education.

Industrial tourism is becoming a more and more popular form of spending free time in the countries of the European Union. That is why, it is advisable to base on standards and experiences already applied. Industrial tourism together with geotourism constitute a significant component that enriches tourist offer of industrial regions.

\section{Literatura (References)}

Gilewska S., 1963, Rzeźba progu środkowotriasowego w okolicy Będzina, Prace Geologiczne IG PAN, nr 44, PWN, Warszawa.

Gilewska S., 1972, Wyżyny Ślqsko-Małopolskie, w: Klimaszewski M. (red.), Geomorfologia Polski, t. 1, PWN, Warszawa.

Hadaś T., 2000, Przyroda i jej przemiany w dziejach Tarnowskich Gór, w: Drabina J. (red.), Historia Tarnowskich Gór, Tarnowskie Góry (Archiwum SMZT).

Karaś-Brzozowska C., 1960, Charakterystyka geomorfologiczna GOP-u, PAN, Warszawa.

Kerber B., 1977, Charakterystyka złóż w rejonie tarnogórskim, w: Pawłowska J. (red), Charakterystyka rud cynku i ołowiu na obszarze ŚląskoKrakowskim, Prace Instytutu Geologicznego, Wydawnictwo geologiczne, Warszawa.

Kondracki J., 2000, Geografia fizyczna Polski, PWN, Warszawa.

Kruczek Z., 2002, Polska Geografia atrakcji turystycznych, Proksenia, Kraków.

Krzykowska Z., Białas I., Gwóźdź K., 1998, Muzeum w Tarnowskich Górach, Tarnowskie Góry.

Lamparska-Wieland M., 2003, Atlas zmian wybranych elementów krajobrazów górniczych i pogórniczych Płaskowyżu Tarnowickiego, Prace Wydziału Nauk o Ziemi Uniwersytetu Śląskiego, 27, Sosnowiec.

Moszny J., 2001, Działalność Kopalni Zabytkowej w latach 1976-2001, w:

Wasielewski R. (red.), XXV rocznica odbudowy Kopalni Zabytkowej Rud Srebronośnych, SMZT, Tarnowskie Góry (Archiwum SMZT).

Piernikarczyk Cz., 2002, 45 lat Sztolni ,Czarnego Pstraga”w Tarnowskich Górach, w: Wasielewski R. (red.), Materiały Sympozjum 45 lat działalności Sztolni ,Czarnego Pstrqga”, SMZT, Tarnowskie Góry (Archiwum SMZT).

Różycki P., 2006, Zarys wiedzy o turystyce, Proksenia, Kraków.

Różycki P., Klasyfikacja współczesnych form turystyki, w: Geoturystyka, 1 (2005).

Słomka T., Kicińska-Świderska A., Geoturystyka - podstawowe pojęcia, w: Geoturystyka, 1 (2004).

Szaflarski J., 1956, Zarys rozwoju uksztaltowania Wyżyny Ślaskiej. Górny Śląsk, Prace i materiały geograficzne, Kraków.

Wyciszczak S., 2000, Przewodnik Tarnogórski, SMZT, Tarnowskie Góry

Wyżgoł F., Wyżgoł E., Błasiak Ł., 2004, Atrakcje turystyczne ziemi tarnogórskiej i okolic. Przewodnik - informator, Biuro Turystyczne „EDFEL", Nakło Śląskie.

Żeglicki J., 1996, O budowie geologicznej, rudach i minerałach rejonu Tarnowskich Gór, SMZT, Tarnowskie Góry (Archiwum SMZT).

Żeglicki J., 2002, Zarys geomorfologii i geologii tarnogórskiego rejonu złożowego, w: Wasielewski R. (red.), Materiały Sympozjum 45 lat dziatalności Sztolni ,Czarnego Pstraga”, SMZT, Tarnowskie Góry (Archiwum SMZT). 